\title{
Human Capital and Economic Growth: The Role of Governance
}

\author{
Ali Muhammad, Abiodun EgBetokun, and Manzoor Hussain MEMON
}

\section{INTRODUCTION}

Economists agree that human capital is an important determinant of economic growth [Arrow (1962); Aghion and Howitt (1992)]. Human capital-led growth generally concludes the positive impact of the two with the help of existing developed theories and empirical evidences.

Nonetheless, the standard empirical result of a direct relationship between human capital (however measured) and economic growth, has been criticised on several fronts. First, the impact of other growth-related factors like quality of education, health of the labour force, inflation, corruption, unemployment, rule of law, etc. should not be ignored. These endogenous characteristics of a country are included in Becker's (1993) definition of human capital. In addition, as noted by Abramovitz (1986), social capabilities are important in the adoption and diffusion of technologies but countries differ in social capabilities. Therefore, to the extent to which human capital contributes to economic growth through innovation, its effect is conditioned by the country's social capabilities which include factors like quality of institutions and governance.

Thus, the effect of human capital on growth could be influenced by the environment within which it is deployed. Particularly, the relationship between human capital and growth might be different for countries with different governance frameworks. Such conditionality is largely ignored in the existing literature. In fact, the stylised fact in the literature is that, all else being equal, higher levels of human capitalparticularly the proportion of the population that is educated - leads to higher economic growth. We re-visit this stylised fact, taking into account the contextual influence of governance. Our premise is as follows: Long-term growth requires the creation of new technologies, or at least an understanding of existing ones. Learning and innovation takes place via human capital. Appropriate policies are required to facilitate learning and innovation and hence human capital. Such policies, as the governance literature suggests, rest upon conducive governance conditions [Avellaneda (2006)]. As a result, the effect of human capital on growth will vary depending on the prevailing governance conditions.

Muhammad Ali<ali.m@uni-jena.de> is PhD Candidate, DFG Research Training Programme, Friedrich Schiller University Jena and the Max Planck Institute of Economics, Bachstrasse, Germany. Abiodun Egbetokun <abiodun.egbetokun@uni-jena.de> is DFG, Research Training Programme, Friedrich Schiller University Jena and the Max Planck Institute of Economics, Bachstrasse, Germany. Manzoor Hussain Memon <manzoorhmemon@yahoo.com> is Economist, Social Policy and Development Centre (SPDC), Karachi. 
This paper, therefore, aims to explore the potential role of governance in the relationship between human capital and economic growth. We divided our sample of 134 countries into 'low', 'medium' and 'high' quality of governance using three similar but different methodologies. Using the Benhabib and Spiegel (1994), and Cohen and Soto (2007) models, we found that human capital has the highest impact on growth in countries with medium quality of governance. Growth in countries with low quality of governance is unaffected by human capital. Relative to the countries with medium quality of governance, human capital has a weaker effect on growth in the best governed countries.

The layout of the paper is led by a short review on previous selected studies on relationship between human capital and growth, and governance and growth. This followed by a conceptual framework of the study i.e. the role of governance in the human capital and growth nexus. Third section state the hypothesis, and the applied econometric model along with a brief note on the data used. Fourth is the empirical setup and estimated result, followed by a conclusion.

\section{HUMAN CAPITAL, GOVERNANCE AND ECONOMIC GROWTH}

It is not possible to ignore the importance of human capital despite the rise of automation. The role of human behind the inventions, innovations and technological advancement is much pronounced in the scientific literature. As far as role of human capital in socio-economic and economic activities is concerned, the immense literature exists on it. There has been much theoretical and empirical investigations found in existing literature examining the human as a source and driver of economic activities and growth. Literature on human capital emphasises the role of human as a very important - if not the most important - source of growth [Arrow (1962); Aghion and Howitt (1992)]. General conceptualisation on the human role as a source of economic activities and economic growth refers to many attributes. These include the education, health, knowledge, skills and many other which are relevant for the economic activities [OECD (1998)]. In the existing literature, some these attributes were much more focused to identify the role of human capital in economic activities and growth.

As far as education is concerned, it is considered as the main ingredient in establishing human capital to ensure the economic growth [Lucas (1988); Barro (1991); Owen's, et al. (2009)]. The quality of the educational system has also been shown as a conditioning variable for the effect of human capital on growth. Primary education is found as the important in least developed countries (LDCs), while secondary education and tertiary education for intermediate countries and OECD countries, respectively [Gemmel (1996)].

Solow's (1956) growth model is considered as the pioneering in theorising the growth phenomenon. The standard neoclassical growth model follows Cobb-Douglas production function, characterised by returns to scale of all inputs with constant positive elasticity of input substitution. Subsequent to neo classical model, different economic growth models extended the theory embodied with human capital as an additional production factor and input for innovation. 
$Y_{t}=A_{t} \cdot f\left(K_{t} \cdot L_{t}\right)$

$K$ is physical capital; $L$ is labour (sometimes interpreted as population)

$t$ is time

$A$ is a technology or efficiency index

Khan (2005) provides evidence to the fact that an increase in human capital investment leads to higher future growth and incomes. The empirical analysis is based on Cobb-Douglas production function augmented with education and health indicators as a quality of human capital. The measure used in the model includes literacy rates, average years of secondary school enrolment and life expectancy. The model also used rate of inflation as a proxy for sound economic policies and the overall quality of institutions. A strong relationship was found between economic policies, quality of institutions such as law and order, absence of corruption and protection of property rights on growth.

Examining the impact of corruption on human capital productivity and growth in Lebanon, Farida and Ahmadi (2006) showed that corruption leads to inefficiency in the economy, reflected in a reduction in the magnitude of coefficients which affect positively on growth. Thus, corruption lowers investment, while the human capital productivity and expenditure effectiveness of the government also reduced.

The discussion so far highlights the fact that, as we claimed at the beginning, human capital is not necessarily directly related to growth. Certain contextual factors play conditioning roles in the relationship. These factors include the quality of the education system, the degree of law and order and a country's current level of development. Our analysis in this paper seeks to extend the existing literature by explicitly examining the role that quality of governance plays in the human capital-growth relationship. To the best of our knowledge, ours is the first study to specifically analyse this contextual role of governance.

Aspects of governance that enable learning and innovation are especially important and considered as critical factor that explain the difference in performance amongst different economies. Governance, reflected in state policies and programmes, and the extent of state intervention in the economy, influences social and economic outputs of a country. The countries that wish to attract international capital and technology are encouraged to improve governance framework of their economy, to disallow rent seeking and corruption [IMF (2002)]. Politics and institutions, according to Avellaneda (2006), are significant to the process of economic growth by affecting the incentives to accumulate, innovate and accommodate change. Evidence on governance roles suggests that countries that has achieved advancement have had implemented sound policies that led to rapid growth, learning and development.

Khan (2007) made a grouping of governance capabilities into what he termed 'market-enhancing' and 'growth-enhancing' governance. The structural limitations of markets in developing economies call for critical governance capacities to enhance growth and development. Also, with effective institutions, technologically backward economies have the potential to 'catch-up' with the technologically advanced nations. Market-enhancing governance capabilities include capability to maintain stable property rights, capability to ensure efficient and low-cost contracting and dispute resolution, and capability to efficiently deliver public goods and services. Efficient markets then in turn ensure the attraction and maximisation of investments 
for technological advancements. In essence, countries with good and adequate governance are more likely to progress economically. China and India provide proof of the impact of governance on economic growth. Growth in both countries has been accompanied by average governance levels better than in most other poor countries [Keefer (2006)]. Political checks and balances play a significant role in improving the countries' governance outcomes.

If policy attempts to attract technology and capital through increasing efficiency of the market then it is less likely to be successful because capital and technology will be attracted to countries with adequate human capital to understand, use and sometimes develop the technology. Moreover, there is no universal strategy for technology acquisition as high growth countries have used very different strategies to achieve high growth rates.

\section{CONCEPTUAL FRAMEWORK}

As exhibited in Figure 1, adequate governance attempts to attract technology and innovation, augmented by the quality of human capital for the absorption and improvement of these technologies. This eventually improves economic development of the country.

Fig. 1. Governance as an Important Factor in Human Capital-led Growth

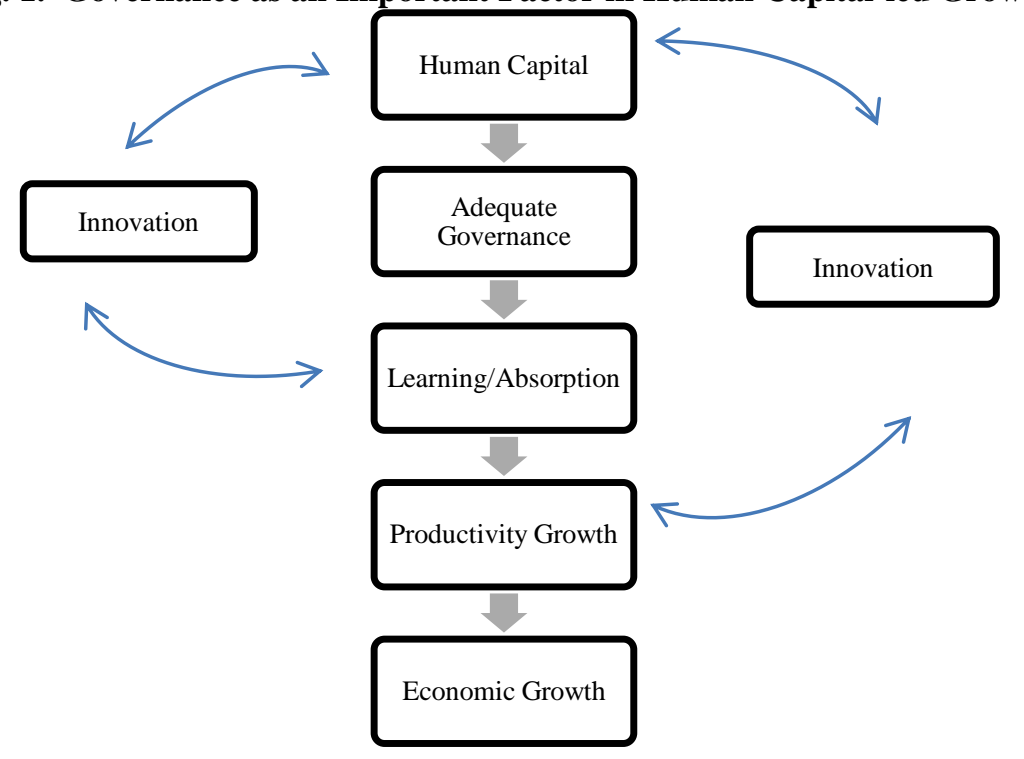

Figure 2 reveals the slow economic growth resulting from weak governance, indicated by deteriorated law and order conditions, corruption, ineffective governance, resulting in inefficient utilisation of human resources. The weak governance in turn reflected from lack of incentives and investment in the economy further weakens and slows down economic growth both in short run and in the long run. 
Fig. 2. Consequences of Weak Governance in Context of Human-led Growth



HYPOTHESIS

The relationship between human capital and economic growth, as discussed before, has been studied in various settings by many authors especially since the 1990s. Some of them were case studies while others were cross country comparisons under different settings. A caveat of these studies, especially in panel data studies, is the universal treatment of countries with respect to quality of governance. We propose that positive and significant relationship between human capital and economic growth might not be universal and that it might depend on the quality of governance in the country. We expect that countries with low quality governance might not be able to utilise its human capital to its potential. In language of econometrics, we expect the relationship between human capital and economic growth to be insignificant for countries with low level of governance.

Hypothesis 1: Relationship between human capital and economic growth is insignificant for countries with low level of governance.

\section{Model}

Human capital-led growth literature provides various different model specifications for empirical estimations. In this paper we used models proposed by Benhabib and Spiegel (1994) (Equation 1) and Cohen and Soto (2007) (Equation 2).

$$
\begin{aligned}
& \Delta \ln Y_{i t}=\beta_{0}+\beta_{1} \ln H C_{i t-1}+\beta_{2} \Delta \ln K_{i t}+\beta_{3} \ln Y_{i t-1}+\beta_{4} \Delta \ln n_{i t}+\varepsilon_{i t} \quad \ldots \\
& \mathrm{Y}=\mathrm{GDP} \text { at current PPP; } \quad \mathrm{HC}=\text { human capital index } \\
& \mathrm{K}=\text { capital stock at current PPP; } \quad \mathrm{n}=\text { population } \\
& \Delta \ln y_{i t}=\beta_{0}+\beta_{1} \ln H C_{i t-1}+\beta_{2} \Delta \ln K_{i t}+\beta_{3} \ln y_{i t-1}+\varepsilon_{i t} \quad \ldots \quad \ldots \\
& \mathrm{y}=\text { GDP per capita at current PPP } \\
& \mathrm{HC}=\text { human capital index; } \quad \mathrm{K}=\text { capital stock at current PPP }
\end{aligned}
$$


Equation 1 models growth in absolute GDP while Equation 2 uses growth in GDP per capita as dependent variable. Both studies used different variants of their main model for estimations i.e. included as an independent variable and as a lagged variable. Since qualification and experience reflect in output after some time lag, the latter attempted to analyse the lagged impact. This study also uses the second variant as shown in the equations above.

\section{DATA}

Data used in this study was taken from two sources; Penn World Tables v.8 and World Governance Indicators of World Bank. Short data descriptions and sources can be found in Appendix Table A1.

\section{Governance Indicators}

World Governance Indicators (WGI) provides six broad types of governance indicators which are generated using various secondary data sources. WGI aims to quantify the aspects of traditions and institutions being exercised in a country which includes the process of government selection, its monitoring and replacement; the ability of government of design and effectively implement sound policies as well as respect of state and citizens. These indicators are rescaled to follow normal distribution within the range of -2.5 and +2.5 (except for political stability which exceeds +2.5 bound). An important note should be made here that higher numbers indicate better 'control' of government not vice versa. For example, value of 1.5 or higher for rule of law as compared to index of 1.0 or lower suggests better control of law. The six governance indicators voice and accountability; political stability and absence of violence / terrorism; government effectiveness; regulatory quality; rule of law; and control of corruption are defined in much detail in WGI documentation. ${ }^{1}$

Fig. 3. Average Governance Index and Human Capital (2011)

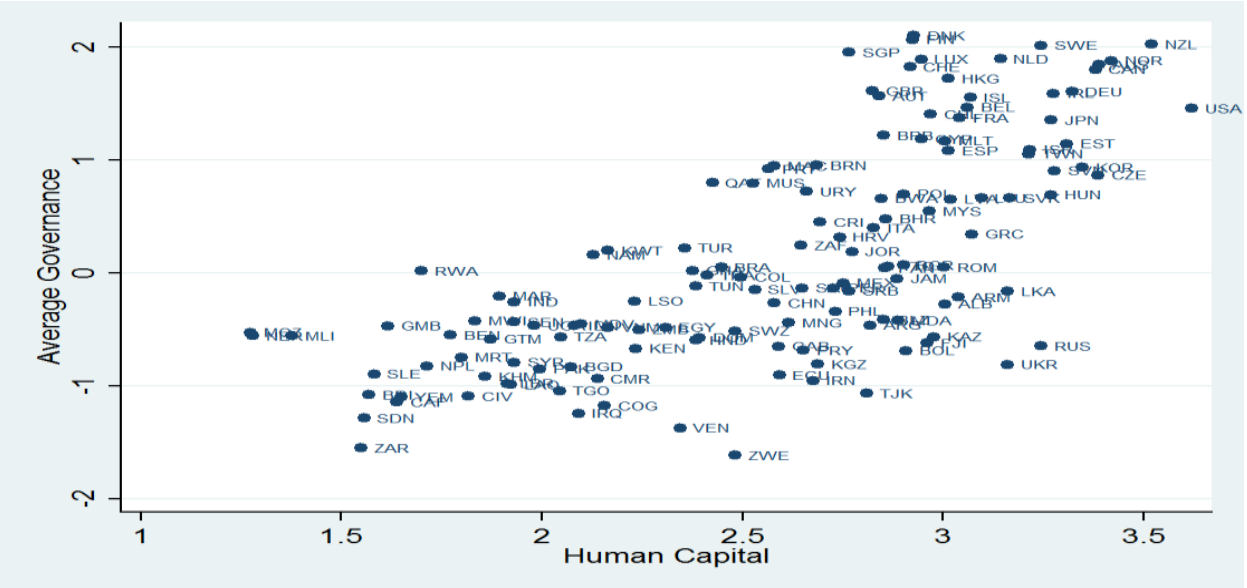

'Voice and accountability' and 'political stability and absence of violence' are least likely to have any influence on the effect of human capital on growth. This is mainly

${ }^{1}$ Definitions are provided in the full dataset of WGI under following link (accessed September $8^{\text {th }}$, 2014) http://info.worldbank.org/governance/wgi/wgidataset.xlsx 
because they have had no relation to technical efficiency. ${ }^{2}$ Therefore these indicators are excluded from the analysis. An additional overall governance indicator was also generated by taking average of government effectiveness, regulatory quality, rule of law and control of corruption to give the broader picture of governance.

Since this study attempts to connect human capital-led growth with governance, it is useful to visually asses the data to compare where countries stand with respect to their human capital as compared to their level of governance. In the following figures, human capital is plotted against all governance indicators used in this study for the year 2011. A first look at all these comparisons clearly shows a similar pattern in all figures. This pattern suggests that a country with high level of governance has high level of human capital. However, same is not true for countries with relatively low level of governance. The distribution at lower level of governance is quite widely spread which suggests that in presence of medium and low level of governance, countries can still have high or low levels of human capital. The impact of the level of human capital on growth in presence of different levels of governance still remains an open question which is the objective of this study. Scatter plots of rest of the governance indicators are available in the appendix.

\section{METHODOLOGICAL FRAMEWORK}

Since the objective of this study is to ascertain whether human capital affects economic growth differently in countries with better or worse level of governance, we split the sample in three groups for each variable i.e. 'low', 'medium' and 'high' level of control. Since WGI warns against over interpretation of minor differences in countries [Kaufmann, et al. (2010)], we used three slightly different schemes to split the sample. If borders of the sections are defined strictly with a number, then two countries on left and right of that border will be assigned to different sections but in reality they might not be very different (as warned by WGI). In order to account for this, we used three different schemes; 'Overlapping' (Figure 4), 'Separated' (Figure 5) and 'Strictly Separated' (Figure 6).

\section{Fig. 4. Scheme 1 - Overlapping Sections}

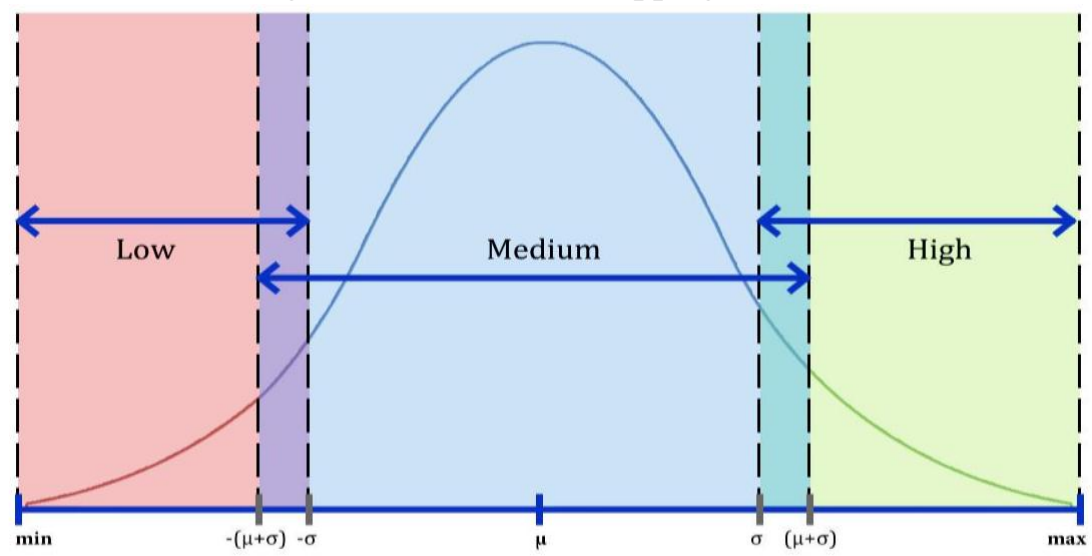

${ }^{2}$ Hurryvansh Aubeeluck, "Institutional Governance and Economic Growth, with special reference to Sub-Saharan Africa", African Studies Association of Australasia and the Pacific-AFSAAP, Conference Proceedings, 36th Annual Conference, 2013. 
Fig. 5. Scheme 2 - Separated Sections

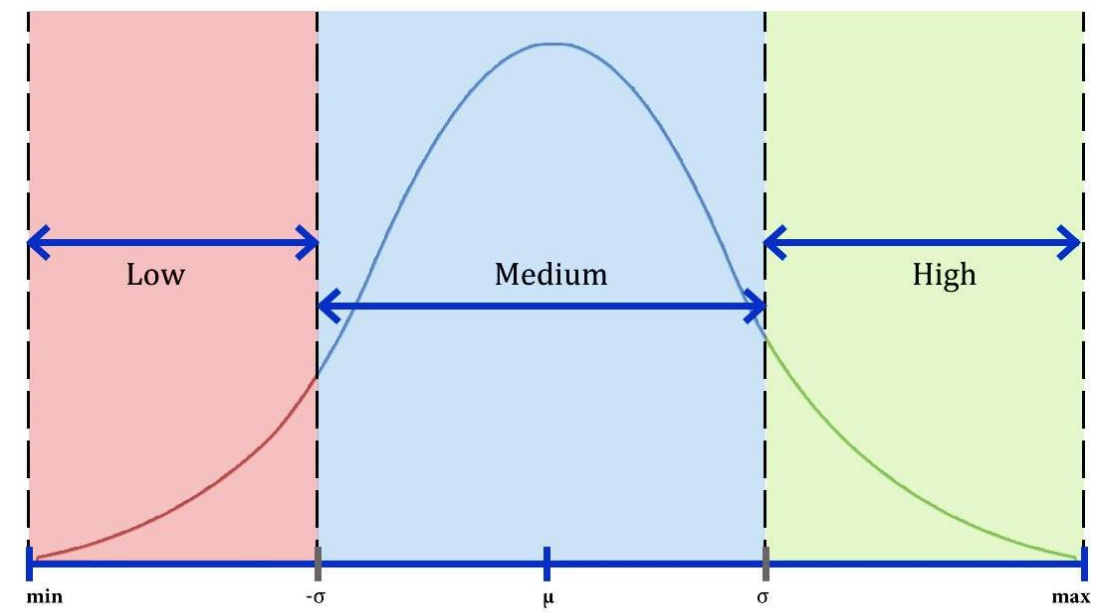

Fig. 6. Scheme 3 - Strictly-Separated Sections

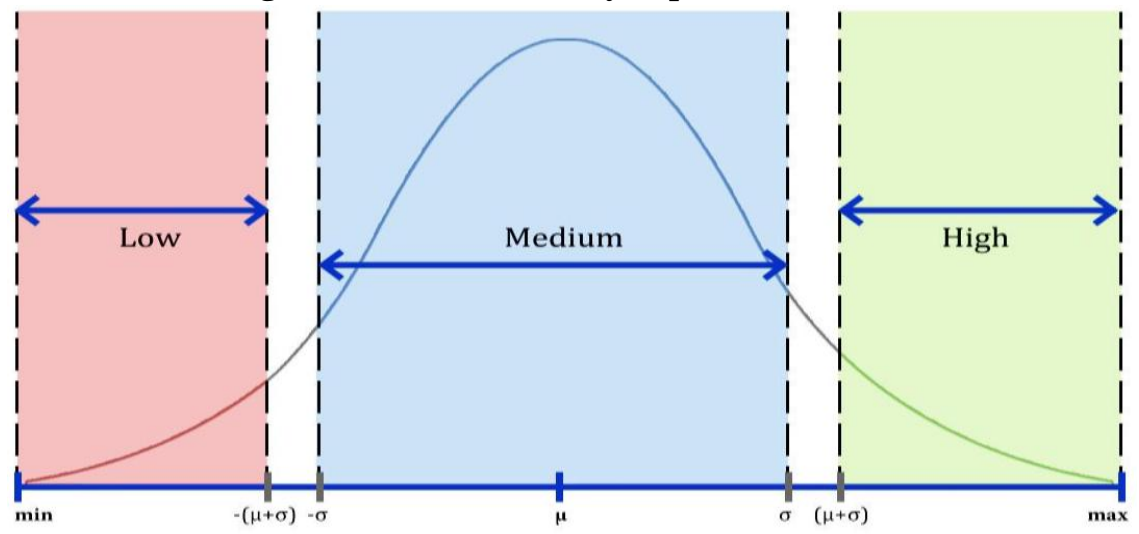

\section{EMPIRICAL SETUP}

Our sample includes a panel data for 134 countries from 1996 to 2011. A large panel data set of countries requires understanding of country-specific effects in a serious manner because of huge significant differences amongst them. Standard empirical methods are used for the analysis. Thus the stationary variables are pooled in the models of OLS, fixed effects and random effects. The latter two also attempts to account for country-specific effects under different assumptions. The determination of fixed or random effects to be used for estimation, we have used the Hausman specification test. Accordingly, fixed effects model was found efficient and consistent. Thus the fixed effects model is used to estimate the parameters of the models in this study.

Sensitivity of the results is checked using two different model specifications provided by the literature as well as using different schemes to distribute the data in three sections. Expectedly, there were minor differences in the estimated coefficients and standard errors when different procedures were used; however results as a whole did not change. Therefore, results of scheme 2, "Separated Sections" for Benhabib and Spiegel 
(1994) model will be reported and interpreted in the text. The other models are available with authors on request.

\section{ESTIMATION RESULTS}

The unrestricted base models of Benhabib and Spiegel (BS) and Cohen and Soto (CS) models are replicated before turning to the restricted models specific to our hypothesis. The results of fixed effects, random effects and pooled OLS estimations are presented in Table 1. The signs of the coefficients were in accordance with the economic theory. One striking feature of the results is very low coefficient of determination as

Table 1

Base Models with Hausman Test for Method Selection

\begin{tabular}{|c|c|c|c|}
\hline \multicolumn{4}{|c|}{ Dependent Cariable: Annualised Difference in Log GDP } \\
\hline & \multicolumn{3}{|c|}{ Benhabib and Spiegel (1994) } \\
\hline & Pooled OLS & Fixed Effects & Random Effects \\
\hline \multirow[t]{2}{*}{$\operatorname{lnHC(t-1)}$} & $0.0209^{*}$ & $0.622 * * *$ & $0.0215^{*}$ \\
\hline & & & $(2.12)$ \\
\hline \multirow[t]{2}{*}{$\Delta \ln K$} & $0.360 * * *$ & $0.345 * * *$ & $0.362 * * *$ \\
\hline & (12.37) & (10.06) & (12.16) \\
\hline \multirow{2}{*}{$\Delta \operatorname{lnn}$} & $0.741 * * *$ & $1.222 * * *$ & $0.721 * * *$ \\
\hline & $(4.89)$ & $(4.88)$ & (4.54) \\
\hline \multirow[t]{2}{*}{$\ln Y(t-1)$} & $-0.00188+$ & $-0.127 * * *$ & $-0.00216+$ \\
\hline & $(-1.72)$ & $(-13.03)$ & $(-1.83)$ \\
\hline \multirow[t]{2}{*}{ Constant } & 0.0140 & $0.860 * * *$ & 0.0169 \\
\hline & (1.09) & (10.68) & $(1.21)$ \\
\hline $\mathrm{N}$ & 2010 & 2010 & 2010 \\
\hline R-sq & 0.099 & 0.135 & - \\
\hline adj. R-sq & 0.098 & 0.071 & - \\
\hline Hausman test & \multicolumn{3}{|c|}{ Chi-Squared: $169.87, \mathrm{P}$-value: 0.000} \\
\hline
\end{tabular}

\begin{tabular}{|c|c|c|c|}
\hline \multicolumn{4}{|c|}{ Dependent Variable: Annualised Difference in Log GDP per Capita } \\
\hline & \multicolumn{3}{|c|}{ Cohen and Soto $(2007)$} \\
\hline & Pooled OLS & Fixed Effects & Random Effects \\
\hline $\operatorname{lnHC}(\mathrm{t}-1)$ & $0.0521 * * *$ & $0.470 * * *$ & $0.0573^{* * *}$ \\
\hline$\Delta \ln K$ & $\begin{array}{c}(4.25) \\
0.360 * * *\end{array}$ & $\begin{array}{c}(8.23) \\
0.355^{* * *}\end{array}$ & $\begin{array}{c}(4.32) \\
0.362 * * *\end{array}$ \\
\hline $\ln Y(t-1)$ & $\begin{array}{c}(12.55) \\
-0.00730^{*} \\
(-3.17)\end{array}$ & $\begin{array}{c}(10.41) \\
-0.148 * * * \\
(-14.12)\end{array}$ & $\begin{array}{c}(12.32) \\
-0.00853 * \\
(-3.42)\end{array}$ \\
\hline Constant & $\begin{array}{c}0.0262+ \\
(1.92)\end{array}$ & $\begin{array}{c}0.887 * * * \\
(11.37)\end{array}$ & $\begin{array}{c}0.0323^{*} \\
(2.18)\end{array}$ \\
\hline $\mathrm{N}$ & 2010 & 2010 & 2010 \\
\hline R-sq & 0.075 & 0.144 & - \\
\hline adj. R-sq & 0.073 & 0.082 & - \\
\hline Hausman test & \multicolumn{3}{|c|}{ Chi-Squared: 188.69, P-value: 0.000} \\
\hline
\end{tabular}

Hausman Test Ho: FE consistent, RE efficient; Ha: FE consistent, RE inconsistent.

$\mathrm{t}$ statistics in parentheses

$+\mathrm{p}<0.10 \quad * \mathrm{p}<0.05 \quad * * \mathrm{p}<0.01 \quad * * * \mathrm{p}<.0001$

compared to the original studies of these models. However, R-squared improves when sub-samples are analysed in later models. Although signs and significance did not change 
with different estimation methods, the coefficients of human capital and some other variables increased significantly when fixed effects were used, i.e. for human capital from 0.020 to 0.622 , from pooled OLS and fixed effect, respectively in BS model. It suggests that controlling for country-specific effects is necessary which is also suggested by Hausman test. The null hypothesis of Hausman test states that fixed effects method is consistent and random effects is efficient while alternate hypothesis states that fixed effects is consistent but random effects is inconsistent. The result of the test suggests that it is better to use fixed effects compared to random effects model as results from random effects model will be inconsistent.

\section{Effect of Human Capital on Economic Growth under Different Levels of Governance}

In order to test our hypothesis, as explained earlier, we divided our dataset into three categories (schemes) based on different levels of governance. These schemes serve as the tool for sensitivity analysis of our results. The scheming is also necessary because small changes in values of governance should not be over-interpreted therefore hard division of the distribution would result in two countries being in different groups even when their differences are quite low. We used three schemes to account for this potential caveat; scheme1: "overlapping sections" where boundaries of the sections overlap with each other, scheme 2: "separated sections" where sections are created with hard division and scheme 3: "strictly separated sections" where there is a gap between the sections to exclude countries with very small differences. While estimations are carried out for all three schemes, we use scheme 2 as our base scheme and the other two schemes as extensions of this scheme for sensitivity analysis. Since results were not sensitive to the schemes, we will interpret the results of both BS and CS models estimated under the base scheme (scheme 2).

\section{Benhabib and Spiegel (BS) Model with Scheme 2}

Estimation results of BS model under scheme 2 are reported in Table 2 where for each governance indicator, results are reported for three sub-samples based on 'low', 'medium' and 'high' levels of governance. An important clarification is due at this point. All governance variables are constructed in a way that high numbers represent better governance. For example, high number for corruption means high level of control for corruption instead of high of level of corruption. Results for the average governance support our hypothesis. The insignificance of human capital in low governance countries clearly states that in countries with low level of governance, human capital does not affect economic growth. Another observation is that magnitude of coefficient of human capital for medium level of governance is more than twice as large as its coefficient for high level of governance. Additionally, significance level was also much higher for countries with medium level of governance. These observations hint towards a threshold level of governance after which higher levels are not beneficial anymore. This also indicates the diminishing returns of human capital investment from a particular threshold level which to some extent can be observed in countries with high level of governance. Similar results were found for regulatory quality and government effectiveness with the exception that coefficient of human capital for countries with medium level of regulatory 
quality was higher but less than twice the magnitude for countries with high level of regulatory quality.

Table 2

Fixed Effects Estimation Results: Scheme 2-Separated Sections (BS Model)

\begin{tabular}{|c|c|c|c|c|c|c|c|c|c|}
\hline & \multicolumn{9}{|c|}{ Dependent variable: Annualised Difference in log GDP } \\
\hline & \multicolumn{9}{|c|}{ Benhabib and Spiegel (1994) } \\
\hline & \multicolumn{3}{|c|}{ Governance Average } & \multicolumn{3}{|c|}{ Rule of Law } & \multicolumn{3}{|c|}{ Control for Corruption } \\
\hline & $\overline{\text { Low }}$ & Medium & High & $\overline{\text { Low }}$ & Medium & High & Low & Medium & High \\
\hline $\operatorname{lnHC}(t-1)$ & $\begin{array}{l}0.566 \\
(1.62)\end{array}$ & $\begin{array}{c}0.641 * * * \\
(8.80)\end{array}$ & $\begin{array}{c}0.284 * \\
(2.38)\end{array}$ & $\begin{array}{l}0.542 * \\
(2.18)\end{array}$ & $\begin{array}{c}0.661 * * * \\
(8.64)\end{array}$ & $\begin{array}{c}0.303^{*} \\
(2.53)\end{array}$ & $\begin{array}{c}0.735^{*} \\
(1.99)\end{array}$ & $\begin{array}{c}0.711^{* * * *} \\
(9.48)\end{array}$ & $\begin{array}{l}0.282^{*} \\
(2.32)\end{array}$ \\
\hline$\Delta \operatorname{lnK}$ & $\begin{array}{c}0.629^{*} \\
(2.80)\end{array}$ & $\begin{array}{c}0.355^{* * * *} \\
(9.14)\end{array}$ & $\begin{array}{c}0.244 * * * \\
(5.68)\end{array}$ & $\begin{array}{c}0.524 * * * \\
(4.67)\end{array}$ & $\begin{array}{c}0.335 * * * \\
(7.42)\end{array}$ & $\begin{array}{c}0.221^{* * *} \\
(5.17)\end{array}$ & $\begin{array}{l}0.609 * \\
(2.05)\end{array}$ & $\begin{array}{c}0.358^{* * * *} \\
(9.10)\end{array}$ & $\begin{array}{c}0.227 * * * \\
(4.97)\end{array}$ \\
\hline$\Delta \operatorname{lnn}$ & $\begin{array}{c}6.606^{* * * *} \\
(4.44)\end{array}$ & $\begin{array}{l}0.688^{*} \\
(2.51)\end{array}$ & $\begin{array}{c}-0.0730 \\
(-0.12)\end{array}$ & $\begin{array}{c}5.755^{* * * *} \\
(5.18)\end{array}$ & $\begin{array}{l}0.768^{*} \\
(2.66)\end{array}$ & $\begin{array}{l}2.064^{*} \\
(2.60)\end{array}$ & $\begin{array}{c}8.004 * * * \\
(4.70)\end{array}$ & $\begin{array}{l}0.919^{*} \\
(3.17)\end{array}$ & $\begin{array}{l}-0.168 \\
(-0.47)\end{array}$ \\
\hline $\ln Y_{(t-1)}$ & $\begin{array}{c}-0.156^{*} \\
(-3.61)\end{array}$ & $\begin{array}{c}-0.103 * * * \\
(-9.39)\end{array}$ & $\begin{array}{c}-0.187 * * * \\
(-9.37)\end{array}$ & $\begin{array}{c}-0.130 * \\
(-3.94)\end{array}$ & $\begin{array}{c}-0.114 * * * \\
(-9.77)\end{array}$ & $\begin{array}{c}-0.208 * * * \\
(-9.99)\end{array}$ & $\begin{array}{c}-0.116^{*} \\
(-2.66)\end{array}$ & $\begin{array}{c}-0.123^{* * * *} \\
(-10.62)\end{array}$ & $\begin{array}{c}-0.184 * * * \\
(-9.47)\end{array}$ \\
\hline Constant & $\begin{array}{l}1.021 * \\
(2.99)\end{array}$ & $\begin{array}{c}0.587 * * * \\
(6.57)\end{array}$ & $\begin{array}{c}2.008 * * * \\
(11.77)\end{array}$ & $\begin{array}{c}0.832 * \\
(3.27)\end{array}$ & $\begin{array}{c}0.688 * * * \\
(7.11)\end{array}$ & $\begin{array}{c}2.248^{* * *} \\
(12.59)\end{array}$ & $\begin{array}{l}0.560 \\
(1.46)\end{array}$ & $\begin{array}{c}0.732 * * * \\
(7.85)\end{array}$ & $\begin{array}{c}2.004 * * * \\
(11.80)\end{array}$ \\
\hline $\mathrm{N}$ & 221 & 1357 & 432 & 292 & 1300 & 418 & 193 & 1418 & 399 \\
\hline R-sq & 0.233 & 0.133 & 0.279 & 0.238 & 0.124 & 0.312 & 0.213 & 0.138 & 0.283 \\
\hline adj. R-sq & 0.112 & 0.059 & 0.213 & 0.134 & 0.045 & 0.241 & 0.049 & 0.063 & 0.207 \\
\hline
\end{tabular}

t statistics in parentheses

$+\mathrm{p}<0.10 \quad * \mathrm{p}<0.05 \quad * * \mathrm{p}<0.01 \quad * * * \mathrm{p}<.0001 "$

Table 2

Fixed Effects Estimation Results: Scheme 2-Separated Sections (BS Model) (Continued)

\begin{tabular}{|c|c|c|c|c|c|c|}
\hline \multicolumn{7}{|c|}{ Dependent Variable: Annualised Difference in Log GDP } \\
\hline & \multicolumn{5}{|c|}{ Benhabib and Spiegel (1994) } & \\
\hline & \multicolumn{3}{|c|}{ Regulatory Quality } & \multicolumn{3}{|c|}{ Government Effectiveness } \\
\hline & $\overline{\text { Low }}$ & Medium & High & $\overline{\text { Low }}$ & Medium & High \\
\hline $\operatorname{lnHC}_{(t-1)}$ & $\begin{array}{l}0.474 \\
(1.53)\end{array}$ & $\begin{array}{c}0.657 * * * * \\
(8.69)\end{array}$ & $\begin{array}{l}0.406^{*} \\
(3.37)\end{array}$ & $\begin{array}{l}0.459 \\
(1.17)\end{array}$ & $\begin{array}{c}0.587 * * * \\
(8.26)\end{array}$ & $\begin{array}{l}0.349^{*} \\
(2.89)\end{array}$ \\
\hline$\Delta \ln K$ & $\begin{array}{l}0.477^{*} \\
(3.06)\end{array}$ & $\begin{array}{c}0.386 * * * * \\
(8.76)\end{array}$ & $\begin{array}{c}0.215^{* * * *} \\
(5.16)\end{array}$ & $\begin{array}{l}0.614^{*} \\
(2.73)\end{array}$ & $\begin{array}{c}0.308 * * * \\
(7.99)\end{array}$ & $\begin{array}{c}0.213 * * * \\
(4.79)\end{array}$ \\
\hline$\Delta \operatorname{lnn}$ & $\begin{array}{c}6.522 * * * \\
(4.70)\end{array}$ & $\begin{array}{l}0.794 * \\
(2.77)\end{array}$ & $\begin{array}{l}0.695 \\
(1.01)\end{array}$ & $\begin{array}{c}6.674 * * * \\
(4.12)\end{array}$ & $\begin{array}{l}0.621^{*} \\
(2.48)\end{array}$ & $\begin{array}{l}0.511 \\
(0.76)\end{array}$ \\
\hline $\ln Y_{(t-1)}$ & $\begin{array}{c}-0.108 * \\
(-3.08)\end{array}$ & $\begin{array}{c}-0.112 * * * \\
(-9.39)\end{array}$ & $\begin{array}{c}-0.192 * * * \\
(-10.15)\end{array}$ & $\begin{array}{c}-0.139 * \\
(-2.91)\end{array}$ & $\begin{array}{c}-0.0947 * * * \\
(-8.93)\end{array}$ & $\begin{array}{c}-0.190 * * * \\
(-9.48)\end{array}$ \\
\hline Constant & $\begin{array}{l}0.650^{*} \\
(2.28)\end{array}$ & $\begin{array}{c}0.671 * * * \\
(6.85)\end{array}$ & $\begin{array}{c}1.907 * * * \\
(12.40)\end{array}$ & $\begin{array}{l}0.891^{*} \\
(2.40)\end{array}$ & $\begin{array}{c}0.545^{* * * *} \\
(6.35)\end{array}$ & $\begin{array}{c}1.976 * * * \\
(11.68)\end{array}$ \\
\hline $\mathrm{N}$ & 215 & 1279 & 516 & 194 & 1364 & 452 \\
\hline $\mathrm{R}$-sq & 0.228 & 0.134 & 0.256 & 0.198 & 0.113 & 0.258 \\
\hline adj. R-sq & 0.126 & 0.057 & 0.185 & 0.079 & 0.040 & 0.187 \\
\hline
\end{tabular}

We did not find support for our hypothesis for control of corruption and rule of law. We found that, contrary to our expectations, human capital had positive and significant coefficient for countries with low level of rule of law and control of corruption. This result suggests that level of corruption and rule of law does not matter for human capital-led growth. Similar to the findings discussed in the last paragraph, we found much higher magnitude of the coefficient of human capital for countries with 
medium level of rule of law and control of corruption vis-à-vis countries with high level governance.

\section{Cohen and Soto (CS) Model with Scheme 2}

Similar to the previous exercise, the estimations were carried out for CS model under scheme 2; the results are presented in Table 3. Contrary to the results of BS model, we found support of our hypothesis for all governance indicators in CS model. We found that the relationship between human capital and growth is insignificant for countries with

Table 3

Fixed Effects Estimation Results: Scheme 2- Separated Sections (CS Model)

\begin{tabular}{|c|c|c|c|c|c|c|c|c|c|}
\hline & \multicolumn{9}{|c|}{$\frac{\text { Dependent Variable: Annualised Difference in Log GDP per Capita }}{\text { Cohen and Soto (2007) }}$} \\
\hline & \multicolumn{3}{|c|}{ Governance Average } & \multicolumn{3}{|c|}{ Rule of Law } & \multicolumn{3}{|c|}{ Control for Corruption } \\
\hline & Low & Medium & $\mathrm{High}$ & Low & Medium & $\overline{\text { High }}$ & Low & Medium & High \\
\hline $\operatorname{lnHC}_{(\mathrm{t}-1)}$ & $\begin{array}{l}0.345 \\
(1.10)\end{array}$ & $\begin{array}{c}0.534 * * * \\
(8.45)\end{array}$ & $\begin{array}{l}0.324^{*} \\
(2.91)\end{array}$ & $\begin{array}{l}0.352 \\
(1.59)\end{array}$ & $\begin{array}{c}0.547 * * * \\
(8.24)\end{array}$ & $\begin{array}{l}0.268^{*} \\
(2.41)\end{array}$ & $\begin{array}{l}0.441 \\
(1.25)\end{array}$ & $\begin{array}{c}0.561 * * * \\
(8.79)\end{array}$ & $\begin{array}{c}0.339 * \\
(2.92)\end{array}$ \\
\hline$\Delta \ln K$ & $\begin{array}{c}0.686^{*} \\
(2.98)\end{array}$ & $\begin{array}{l}0.361 * * * \\
(9.36)\end{array}$ & $\begin{array}{l}0.253 * * * \\
(6.05)\end{array}$ & $\begin{array}{c}0.541^{* * *} \\
(4.66)\end{array}$ & $\begin{array}{l}0.346^{* * *} \\
(7.74)\end{array}$ & $\begin{array}{l}0.238 * * * \\
(5.70)\end{array}$ & $\begin{array}{c}0.758^{*} \\
(2.46)\end{array}$ & $\begin{array}{l}0.363^{* * *} \\
(9.28)\end{array}$ & $\begin{array}{l}0.244 * * * \\
(5.48)\end{array}$ \\
\hline $\ln y_{(t-1)}$ & $\begin{array}{c}-0.221 * * * \\
(-4.45)\end{array}$ & $\begin{array}{c}-0.124 * * * \\
(-10.80)\end{array}$ & $\begin{array}{c}-0.263^{* * * *} \\
(-11.31)\end{array}$ & $\begin{array}{c}-0.165 * * * \\
(-4.48)\end{array}$ & $\begin{array}{c}-0.142 * * * \\
(-11.43)\end{array}$ & $\begin{array}{c}-0.256^{* * *} \\
(-11.00)\end{array}$ & $\begin{array}{c}-0.172 * \\
(-3.23)\end{array}$ & $\begin{array}{c}-0.141 * * * \\
(-11.84)\end{array}$ & $\begin{array}{c}-0.266 * * * \\
(-10.87)\end{array}$ \\
\hline Constant & $\begin{array}{c}1.384 * * * \\
(4.10)\end{array}$ & $\begin{array}{c}0.607 \text { *** } \\
(7.30)\end{array}$ & $\begin{array}{c}2.360 * * * \\
(13.59)\end{array}$ & $\begin{array}{c}1.002^{* * * *} \\
(4.16)\end{array}$ & $\begin{array}{c}0.755^{* * *} \\
(8.20)\end{array}$ & $\begin{array}{c}2.349 * * * \\
(13.71)\end{array}$ & $\begin{array}{l}0.983 * \\
(2.65)\end{array}$ & $\begin{array}{c}0.731 * * * \\
(8.42)\end{array}$ & $\begin{array}{c}2.380 * * * \\
(13.02)\end{array}$ \\
\hline $\mathrm{N}$ & 221 & 1357 & 432 & 292 & 1300 & 418 & 193 & 1418 & 399 \\
\hline$R$-sq & 0.163 & 0.147 & 0.326 & 0.160 & 0.145 & 0.343 & 0.109 & 0.153 & 0.322 \\
\hline adj. R-sq & 0.036 & 0.076 & 0.266 & 0.049 & 0.069 & 0.277 & -0.070 & 0.081 & 0.253 \\
\hline
\end{tabular}

$\mathrm{t}$ statistics in parentheses

$+\mathrm{p}<0.10 \quad * \mathrm{p}<0.05 \quad * * \mathrm{p}<0.01 \quad * * * \mathrm{p}<.0001 "$

Table 3

Fixed Effects Estimation Results: Scheme 2- Separated Sections (CS Model) (Continued)

\begin{tabular}{|c|c|c|c|c|c|c|}
\hline & \multirow{2}{*}{\multicolumn{6}{|c|}{$\begin{array}{c}\text { Dependent Variable: Annualised Difference in Log GDP per Capita } \\
\text { Benhabib and Spiegel (1994) }\end{array}$}} \\
\hline & & & & & & \\
\hline & \multicolumn{3}{|c|}{ Regulatory Quality } & \multicolumn{3}{|c|}{ Government Effectiveness } \\
\hline & Low & Medium & High & Low & Medium & High \\
\hline $\operatorname{lnHC}(t-1)$ & $\begin{array}{l}0.289 \\
(1.00)\end{array}$ & $\begin{array}{l}0.514 * * * \\
(7.92)\end{array}$ & $\begin{array}{l}0.396^{*} \\
(3.53)\end{array}$ & $\begin{array}{l}0.174 \\
(0.50)\end{array}$ & $\begin{array}{l}0.492 * * * \\
(7.97)\end{array}$ & $\begin{array}{l}0.382^{*} \\
(3.39)\end{array}$ \\
\hline$\Delta \ln K$ & $\begin{array}{c}0.546^{*} \\
(3.41)\end{array}$ & $\begin{array}{l}0.392 * * * \\
(8.93)\end{array}$ & $\begin{array}{c}0.231 * * * \\
(5.69)\end{array}$ & $\begin{array}{r}0.726^{*} \\
(3.22)\end{array}$ & $\begin{array}{l}0.318 * * * \\
(8.28)\end{array}$ & $\begin{array}{l}0.228 * * * \\
(5.29)\end{array}$ \\
\hline $\ln y_{(t-1)}$ & $\begin{array}{l}-0.152 * \\
(-3.77)\end{array}$ & $\begin{array}{l}-0.132 * * * \\
(-10.55)\end{array}$ & $\begin{array}{c}-0.239 * * * \\
(-11.52)\end{array}$ & $\begin{array}{l}-0.210^{*} \\
(-3.94)\end{array}$ & $\begin{array}{c}-0.116^{* * * *} \\
(-10.26)\end{array}$ & $\begin{array}{c}-0.263 * * * \\
(-11.20)\end{array}$ \\
\hline Constant & $\begin{array}{l}0.944 * \\
(3.53)\end{array}$ & $\begin{array}{l}0.684 * * * \\
(7.47)\end{array}$ & $\begin{array}{c}2.022 * * * \\
(13.68)\end{array}$ & $\begin{array}{l}1.380^{*} \\
(3.82)\end{array}$ & $\begin{array}{c}0.574 * * * \\
(7.07)\end{array}$ & $\begin{array}{c}2.290 * * * \\
(13.28)\end{array}$ \\
\hline $\mathrm{N}$ & 215 & 1279 & 516 & 194 & 1364 & 452 \\
\hline R-sq & 0.142 & 0.147 & 0.289 & 0.128 & 0.128 & 0.303 \\
\hline adj. R-sq & 0.034 & 0.072 & 0.222 & 0.004 & 0.057 & 0.239 \\
\hline
\end{tabular}

$\mathrm{t}$ statistics in parentheses

$+\mathrm{p}<0.10 \quad * \mathrm{p}<0.05 \quad * * \mathrm{p}<0.01 * * * \mathrm{p}<.0001 "$

low level of 'governance (average)', 'rule of law', 'control of corruption', 'regulatory quality' and 'government effectiveness'. This finding suggests that human capital in countries with low level of governance will not increase economic growth unless it is combined with the policy of improving governance. While coefficients of countries with 
medium level governance reveals similar results as in BS model and are highly significant in all governance indicators vis-à-vis countries with high level of governance.

\section{CONCLUDING REMARKS}

Empirical literature on relationship between human capital and economic growth provides contradictory results. This has been studied by number of authors by using different models, settings, data set and time specifications. The cross country comparisons implicitly assume homogenous governance systems/quality in all countries which, in our opinion, is a strong assumption. In this study we used data for 134 countries and divided the sample based on the level of governance in the countries. Using fixed effects model for estimation, in most of the cases we found that the relationship between human capital and economic growth is insignificant (or weaker) for countries with low level of governance. We also found that coefficient of human capital was larger for countries with medium level of governance vis-à-vis countries with high level of governance. This finding hint towards the threshold level of governance after which there might be diminishing returns. The results were robust to the method of data division.

There is a potentially important role of human capital in supporting countries' economic growth. However, the findings in this paper suggest that increase in human capital might not reflect in the economic growth if the country has bad governance. In the absence of proper regulatory framework and control of corruption, the system will not be able to utilise and optimise its human capital potential.

This study extends the literature that suggests the need to strengthen the link between human capital and economic growth. The novelty of the paper lies in the fact that it uncovers the role of governance as a conditioning factor in this link. In general, better-governed states make better use of their human capital and thus tend to accumulate more wealth. However, comparing averagely well governed states with the best-governed ones reveals that there might be a threshold beyond which the role of governance in human capital-led growth. The research implication of this finding is two-fold: one, the widely reported impact of human capital on economic growth, while positive, might haven been exaggerated; two, future research on the link between human capital and economic growth needs to take the conditioning effect of governance into account. 


\section{APPENDIX}

Table A1

\begin{tabular}{|c|c|c|}
\hline Variable & Description/Unit & Source \\
\hline $\bar{Y}$ & Output-side real GDP at current PPPs (in mil. 2005US\$) & $\begin{array}{c}\text { Penn World } \\
\text { Tables } 8.0\end{array}$ \\
\hline $\mathrm{n}$ & Population (in millions) & $\begin{array}{c}\text { Penn World } \\
\text { Tables } 8.0\end{array}$ \\
\hline $\mathrm{y}$ & $\mathrm{Y} / \mathrm{n}$ & $\begin{array}{c}\text { Penn World } \\
\text { Tables } 8.0\end{array}$ \\
\hline $\mathrm{HC}$ & $\begin{array}{l}\text { Index of human capital per person, based on years of } \\
\text { schooling (Barro/Lee, 2012) and returns to education } \\
\text { (Psacharopoulos, 1994) }\end{array}$ & $\begin{array}{c}\text { Penn World } \\
\text { Tables } 8.0\end{array}$ \\
\hline $\mathrm{K}$ & Capital stock at current PPPs (in mil. 2005US\$) & $\begin{array}{c}\text { Penn World } \\
\text { Tables } 8.0\end{array}$ \\
\hline ROL & Rule of Law index (range -2.5 to 2.5 ) & $\begin{array}{l}\text { World } \\
\text { Governance } \\
\text { Indicators }\end{array}$ \\
\hline COR & Control of Corruption index (range -2.5 to 2.5 ) & $\begin{array}{l}\text { World } \\
\text { Governance } \\
\text { Indicators }\end{array}$ \\
\hline Govt.Eff & Government Effectiveness index (range -2.5 to 2.5 ) & $\begin{array}{l}\text { World } \\
\text { Governance } \\
\text { Indicators }\end{array}$ \\
\hline REG & Regulatory Environment index (range -2.5 to 2.5 ) & $\begin{array}{l}\text { World } \\
\text { Governance } \\
\text { Indicators }\end{array}$ \\
\hline Gov & Average Governance (ROL+COR+Govt.Eff+REG)/4 & $\begin{array}{l}\text { World } \\
\text { Governance } \\
\text { Indicators }\end{array}$ \\
\hline
\end{tabular}

Table A2

Correlation Matrix

\begin{tabular}{lccccccc}
\hline & $\Delta \ln \mathrm{Y}$ & $\Delta \ln \mathrm{ln}$ & $\operatorname{lnh}(\mathrm{t}-1)$ & $\Delta \operatorname{lnck}$ & $\Delta \operatorname{lnn}$ & $\ln \mathrm{Y}(\mathrm{t}-1)$ & $\ln (\mathrm{t}-1)$ \\
\hline$\Delta \ln \mathrm{Y}$ & 1 & & & & & & \\
$\Delta \ln y$ & 0.9862 & 1 & & & & & \\
$\operatorname{lnh}(\mathrm{t}-1)$ & -0.0588 & 0.0249 & 1 & & & & \\
$\Delta \operatorname{lnck}$ & 0.2937 & 0.2573 & -0.1378 & 1 & & & \\
$\Delta \operatorname{lnn}$ & 0.1702 & 0.0044 & -0.5027 & 0.2417 & 1 & & \\
$\ln \mathrm{Y}(\mathrm{t}-1)$ & -0.0584 & -0.0126 & 0.4433 & -0.035 & -0.2772 & 1 & 1 \\
$\ln (\mathrm{t}-1)$ & -0.0497 & -0.0031 & 0.779 & -0.0327 & -0.2811 & 0.5527 & 1 \\
\hline & & \multicolumn{7}{c}{ Table A3 } & & &
\end{tabular}


Descriptive Statistics

\begin{tabular}{lccccc}
\hline Variable & Obs & Mean & Std. Dev. & Min & Max \\
\hline$\Delta \ln Y$ & 2010 & 0.041222 & 0.090408 & -0.93698 & 1.12034 \\
$\Delta \operatorname{lny}$ & 2010 & 0.026929 & 0.089091 & -0.94246 & 1.115328 \\
$\operatorname{lnh}(\mathrm{t}-1)$ & 2010 & 0.869949 & 0.252762 & 0.127135 & 1.286128 \\
$\Delta \operatorname{lnck}$ & 2010 & 0.05291 & 0.067864 & -0.4877 & 0.971869 \\
$\Delta \operatorname{lnn}$ & 2010 & 0.014293 & 0.014988 & -0.01841 & 0.185883 \\
$\operatorname{lnY}(\mathrm{t}-1)$ & 2010 & 10.99621 & 1.964236 & 5.704933 & 16.39151 \\
$\operatorname{lny}(\mathrm{t}-1)$ & 2010 & 8.717786 & 1.334267 & 4.914746 & 11.60562 \\
Avg.Governance & 2010 & 0.116643 & 0.970479 & -2.12292 & 2.201406 \\
Rule of Law & 2010 & 0.049999 & 1.002271 & -2.22985 & 1.99964 \\
Control of Corruption & 2010 & 0.080258 & 1.042928 & -2.05746 & 2.585616 \\
Regulatory Quality & 2010 & 0.187996 & 0.935579 & -2.41273 & 2.247345 \\
Government Effectiveness & 2010 & 0.14832 & 0.998738 & -1.98201 & 2.429652 \\
\hline
\end{tabular}

Table A4

Fixed Effects Estimation Results: Scheme 3-Strictly Separated Sections (BS Model)

\begin{tabular}{|c|c|c|c|c|c|c|c|c|c|}
\hline & \multicolumn{9}{|c|}{$\frac{\text { Dependent Variable: Annualised Difference in Log GDP }}{\text { Benhabib and Spiegel (1994) }}$} \\
\hline & \multicolumn{3}{|c|}{ Governance Average } & \multicolumn{3}{|c|}{ Rule of Law } & \multicolumn{3}{|c|}{ Control for Corruption } \\
\hline & Low & Medium & High & Low & Medium & High & Low & Medium & High \\
\hline \multirow[t]{2}{*}{$\operatorname{lnHC}(t-1)$} & 0.625 & $0.641 * * *$ & $0.323 *$ & $0.542+$ & $0.661 * * *$ & $0.363^{*}$ & $1.392 *$ & $0.711 * * *$ & $0.300^{*}$ \\
\hline & $(1.12)$ & $(8.80)$ & $(2.57)$ & (1.83) & (8.64) & $(2.90)$ & $(2.22)$ & $(9.48)$ & $(2.32)$ \\
\hline \multirow[t]{2}{*}{$\Delta \ln K$} & 0.379 & $0.355^{* * *}$ & $0.230 * * *$ & $0.536 * * *$ & $0.335 * * *$ & $0.222 * * *$ & 0.348 & $0.358 * * *$ & $0.214 * * *$ \\
\hline & (1.07) & (9.14) & (4.95) & $(4.32)$ & $(7.42)$ & (5.13) & $(0.85)$ & (9.10) & (4.45) \\
\hline \multirow[t]{2}{*}{$\Delta \operatorname{lnn}$} & 7.417 *** & $0.688 *$ & 0.898 & $5.723 * * *$ & $0.768^{*}$ & $2.124 *$ & 11.76 **** & $0.919 *$ & 0.0626 \\
\hline & $(4.19)$ & $(2.51)$ & $(1.26)$ & $(4.79)$ & $(2.66)$ & (2.64) & (5.20) & (3.17) & $(0.10)$ \\
\hline \multirow[t]{2}{*}{$\ln Y_{(t-1)}$} & $-0.149^{*}$ & $-0.103 * * *$ & $-0.195 * * *$ & $-0.132 *$ & $-0.114 * * *$ & $-0.217 * * *$ & $-0.124 *$ & $-0.123 * * *$ & $-0.186 * * *$ \\
\hline & $(-2.70)$ & $(-9.39)$ & $(-9.36)$ & $(-3.62)$ & $(-9.77)$ & $(-10.18)$ & $(-2.08)$ & $(-10.62)$ & $(-8.70)$ \\
\hline \multirow[t]{2}{*}{ Constant } & $0.910^{*}$ & $0.587 * * *$ & $2.062 * * *$ & $0.851 *$ & $0.688 * * *$ & $2.303 * * *$ & 0.137 & $0.732 * * *$ & $2.009 * * *$ \\
\hline & (2.10) & $(6.57)$ & (11.37) & (3.08) & (7.11) & (12.63) & $(0.26)$ & (7.85) & (10.75) \\
\hline $\mathrm{N}$ & 153 & 1357 & 395 & 259 & 1300 & 397 & 123 & 1418 & 382 \\
\hline $\mathrm{R}-\mathrm{sq}$ & 0.224 & 0.133 & 0.273 & 0.234 & 0.124 & 0.320 & 0.296 & 0.138 & 0.262 \\
\hline adj. R-sq & 0.099 & 0.059 & 0.202 & 0.121 & 0.045 & 0.254 & 0.132 & 0.063 & 0.185 \\
\hline
\end{tabular}

\begin{tabular}{lll}
\hline t statistics in parentheses & \\
$+\mathrm{p}<0.10 \quad * \mathrm{p}<0.05 \quad * * \mathrm{p}<0.01 \quad * * * \mathrm{p}<.0001 "$
\end{tabular}

Table A5

Fixed Effects Estimation Results: Scheme 3-Strictly Separated Sections 
(BS Model) (Continued)

\begin{tabular}{|c|c|c|c|c|c|c|}
\hline & \multicolumn{6}{|c|}{$\frac{\text { Dependent Variable: Annualised Difference in Log GDP }}{\text { Benhabib and Spiegel (1994) }}$} \\
\hline & \multicolumn{3}{|c|}{ Regulatory Quality } & \multicolumn{3}{|c|}{ Government Effectiveness } \\
\hline & Low & Medium & High & Low & Medium & $\overline{\text { High }}$ \\
\hline \multirow[t]{2}{*}{$\ln \mathrm{HC}_{(\mathrm{t}-1)}$} & $0.756+$ & $0.657 * * *$ & $0.370^{*}$ & 0.702 & $0.587 * * *$ & $0.270^{*}$ \\
\hline & $(1.73)$ & $(8.69)$ & $(2.79)$ & $(1.45)$ & $(8.26)$ & $(2.16)$ \\
\hline \multirow[t]{2}{*}{$\Delta \ln K$} & 0.376 & $0.386^{* * *} *$ & $0.190 * * *$ & 0.434 & $0.308 * * *$ & $0.173 *$ \\
\hline & (1.24) & $(8.76)$ & (4.12) & (1.18) & (7.99) & (3.74) \\
\hline \multirow[t]{2}{*}{$\Delta \ln n$} & $7.130 * * *$ & $0.794 *$ & 0.468 & $6.651 *$ & $0.621^{*}$ & 0.885 \\
\hline & $(4.28)$ & $(2.77)$ & $(0.68)$ & $(3.66)$ & $(2.48)$ & $(1.31)$ \\
\hline \multirow[t]{2}{*}{$\ln Y_{(t-1)}$} & $-0.159 *$ & $-0.112 * * *$ & $-0.168 * * *$ & $-0.188 *$ & $-0.0947 * * *$ & $-0.177^{*} * *$ \\
\hline & $(-3.26)$ & $(-9.39)$ & $(-8.18)$ & $(-3.11)$ & $(-8.93)$ & $(-8.60)$ \\
\hline \multirow[t]{2}{*}{ Constant } & $0.977 *$ & $0.671 * * *$ & $1.674 * * *$ & $1.184 *$ & $0.545^{* * *} *$ & $1.912 * * *$ \\
\hline & $(2.58)$ & $(6.85)$ & $(9.82)$ & $(2.64)$ & $(6.35)$ & $(10.81)$ \\
\hline $\mathrm{N}$ & 161 & 1279 & 401 & 147 & 1364 & 392 \\
\hline R-sq & 0.241 & 0.134 & 0.218 & 0.225 & 0.113 & 0.250 \\
\hline adj. R-sq & 0.139 & 0.057 & 0.133 & 0.102 & 0.040 & 0.172 \\
\hline
\end{tabular}

$\mathrm{t}$ statistics in parentheses

$+\mathrm{p}<0.10 * \mathrm{p}<0.05 * * \mathrm{p}<0.01 * * * \mathrm{p}<.0001 "$

Table A6

Fixed Effects Estimation Results: Scheme 3-Strictly Separated Sections (CS Model)

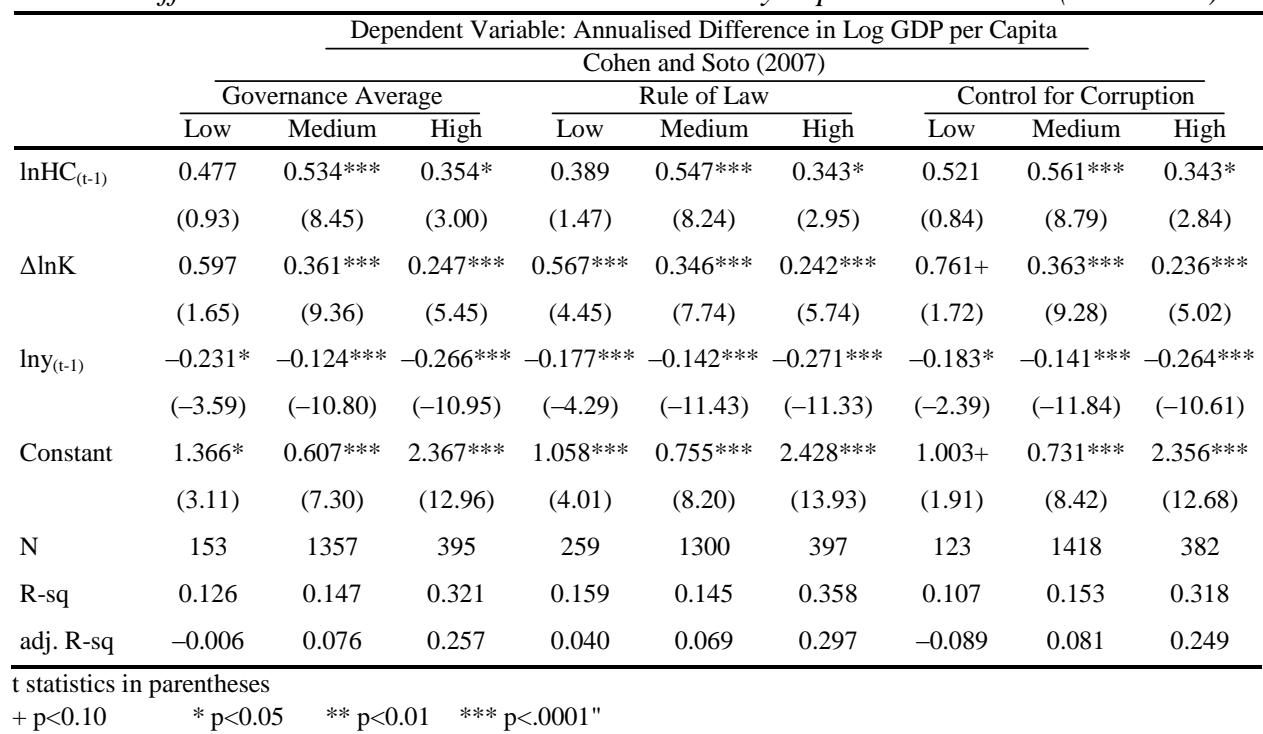

Table A7

Fixed Effects Estimation Results: Scheme 3-Strictly Separated Sections (CS Model) (Continued) 


\begin{tabular}{|c|c|c|c|c|c|c|}
\hline & \multicolumn{6}{|c|}{ Dependent Variable: Annualised Difference in Log GDP per Capita } \\
\hline & \multicolumn{6}{|c|}{ Benhabib and Spiegel (1994) } \\
\hline & \multicolumn{3}{|c|}{ Regulatory Quality } & \multicolumn{3}{|c|}{ Government Effectiveness } \\
\hline & Low & Medium & High & Low & Medium & High \\
\hline \multirow{2}{*}{$\ln \mathrm{HC}_{(\mathrm{t}-1)}$} & 0.632 & $0.514 * * *$ & $0.386^{*}$ & 0.262 & $0.492 * * *$ & $0.296^{*}$ \\
\hline & $(1.54)$ & $(7.92)$ & $(3.14)$ & $(0.63)$ & $(7.97)$ & $(2.51)$ \\
\hline \multirow[t]{2}{*}{$\Delta \ln K$} & 0.493 & $0.392 * * *$ & $0.204 * * *$ & 0.574 & $0.318 * * *$ & $0.191 * * *$ \\
\hline & (1.57) & (8.93) & $(4.52)$ & $(1.55)$ & (8.28) & $(4.23)$ \\
\hline \multirow[t]{2}{*}{$\ln y_{(t-1)}$} & $-0.230 * * *$ & $-0.132 * * *$ & $-0.222 * * *$ & $-0.285^{* * *}$ & $-0.116 * * *$ & $-0.240 * * *$ \\
\hline & $(-4.09)$ & $(-10.55)$ & $(-9.71)$ & $(-4.23)$ & $(-10.26)$ & $(-9.96)$ \\
\hline \multirow[t]{2}{*}{ Constant } & $1.307 *$ & $0.684 * * *$ & $1.870 * * *$ & $1.821 * * *$ & $0.574 * * *$ & $2.170 * * *$ \\
\hline & (3.73) & (7.47) & (11.32) & (4.19) & (7.07) & (12.15) \\
\hline $\mathrm{N}$ & 161 & 1279 & 401 & 147 & 1364 & 392 \\
\hline R-sq & 0.149 & 0.147 & 0.261 & 0.160 & 0.128 & 0.293 \\
\hline adj. R-sq & 0.042 & 0.072 & 0.184 & 0.034 & 0.057 & 0.222 \\
\hline
\end{tabular}

$\mathrm{t}$ statistics in parentheses

$+\mathrm{p}<0.10 \quad * \mathrm{p}<0.05 \quad * * \mathrm{p}<0.01 \quad * * * \mathrm{p}<.0001 "$

Fig. A1. Control of Corruption and Human Capital (2011)



Fig. A2. Regulatory Quality and Human Capital (2011) 


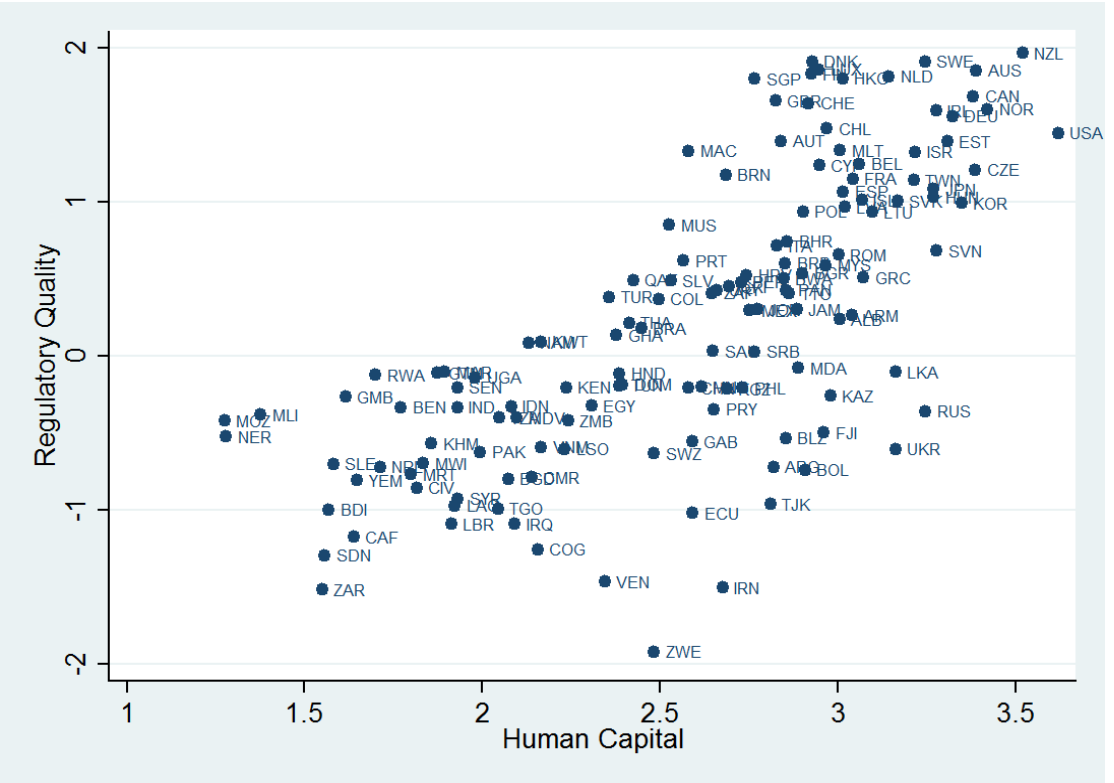

Fig. A3. Government Efficiency and Human Capital (2011)

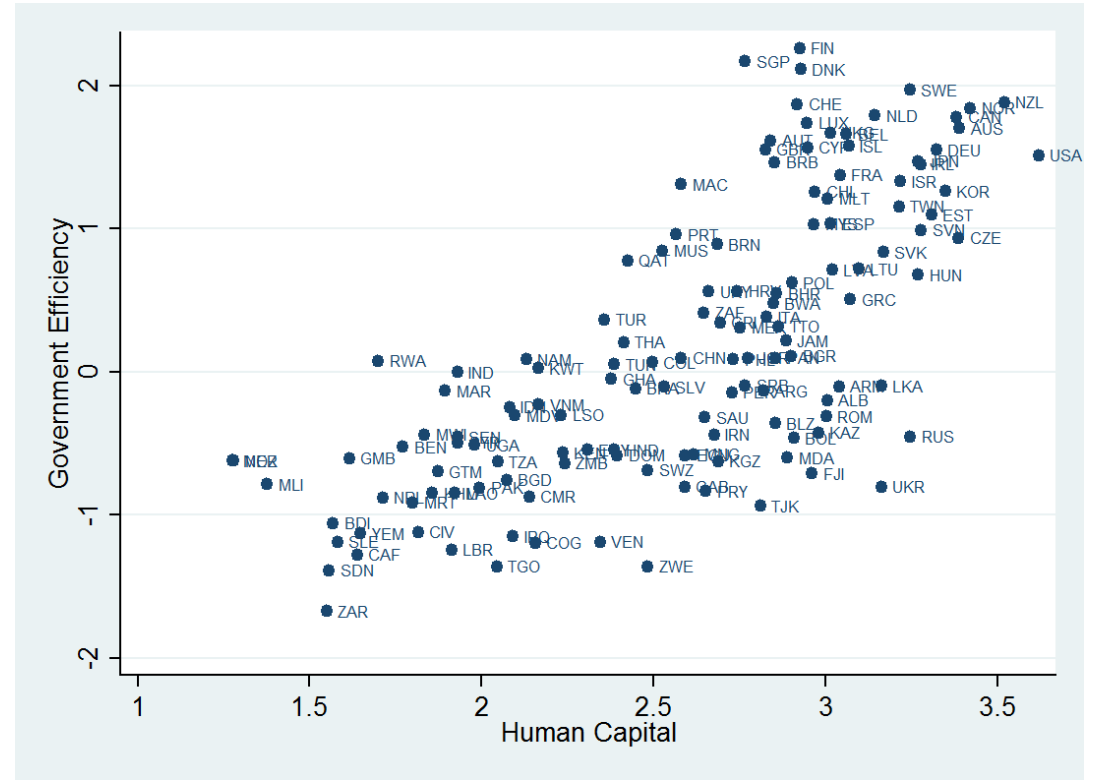

\section{REFERENCES}

Abramovitz, Moses (1986) Catching Up, Forging Ahead, and Falling Behind. The Journal of Economic History 46: 2, 385-406.

Aghion, P. and P. Howitt (1992) A Model of Growth Through Creative Destruction. Econometrica 60:2, 323-351.

Arrow, K. J. (1962) The Economic Implications of Learning By Doing. Review of

Economic Studies 29, 155-173. 
Aubeeluck, Hurryvansh (2013) Institutional Governance and Economic Growth, with special reference to Sub-Saharan Africa, African Studies Association of Australasia and the Pacific - AFSAAP, $36^{\text {th }}$ Annual Conference.

Avellaneda, S. D. (2006) Good Governance, Institutions and Economic Development: Beyond the Conventional Wisdom. Paper presented at the Forum de Recerca, Departament de Ciencies Politiques I Socials, Universitat Pompeu Fabra, Barcelona 3 de Mayo 2006.

Barro, R. (1991) Economic Growth in a Cross Section of Countries. The Quarterly Journal of Economics 106:2, 407.

Becker, G. S. (1993) Human Capital: A Theoretical and Empirical Analysis, with Special Reference to Education (3rd ed.). Chicago: University of Chicago Press.

Benhabib, J. and M. M. Spiegel (1994) The Role of Human Capital in Economic Development: Evidence from Aggregate Cross-Country Data. Journal of Monetary Economics 34;2, 143-173.

Cohen, D. and M. Soto (2007) Growth and Human Capital: Good Data, Good Results. Journal of Economic Growth 12:1, 51-76.

Elias, Lic. Silvina. and Lic. M. del R. Fernandez (2000) Human Capital Investment, Income Levels and Economic Grotwh in Latin American Countries. Departamento de Economics. Universidad Nacional Del Sur,

Farida, M. and F. Z. Ahmadi-Esfahani (2006) Corruption and Economic Growth in Lebanon. Australian Agricultural and Resource Economics Society, 52nd Annual Conference.

Gemmell, N. (1996) Evaluating the Impacts of Human Capital Stocks and Accumulation on Economic Growth: Some New Evidence. Oxford Bulletin of Economics and Statistics 58:1, 9-28.

Hoti, A. (2003) Human Capital and Unemployment in Transition Economies: The Case of Kosova. International Conference of the Faculty o Economic Sarajevo.

IMF (2002) Governance, Corruption, and Economic Performance. International Monetary Fund.

Johansen, S. (1988) Statistical Analysis of Cointegration Vectors. Journal of Economic Dynamics and Control 12, 231-54.

Johansen, S. (1991) Estimation and Hypothesis testing of Cointegration Vectors in Gaussian Vector Autoregressive Models. Econometrica 59, 1551-1580.

Johansen, S. (1992) Determination of Cointegration Rank in the Presence of a Linear Trend. Oxford Bulletin of Economics and Statistics 54, 383-397.

Johansen, S. and K. Juselius (1990) Maximum Likelihood Estimation and Inference on Cointegration with Applications to the Demand for Money. Oxford Bulletin of Economics and Statistics 52:2, 169-210.

Kaufmann, Daniel, Aart Kraay, and Massimo Mastruzzi (2010) The Worldwide Governance Indicators: Methodology and Analytical Issues. (World Bank Policy Research Working Paper No. 5430). Available at SSRN: http://ssrn.com/abstract=1682130

Keefer, P. (2006) Governance and Economic Growth in China and India. In Dancing with Giants: China, India, and the Global Economy. Ch. 7. 
Khan, M. (2007) Governance, Economic Growth and Development since the 1960s. Web:

http://eprints.soas.ac.uk/9921/1/DESA_Governance_Economic_Growth_and_Develo pment_since_1960s.pdf accessed 29-08-2014

Khan, Mushtaq H. (2005) Review of DFID's Governance Target Strategy Paper. Commissioned paper submitted to DFID. Department for International Development, London. (as cited by Khan 2007).

Lic, Silvina Elias and Lic. M. del R. Fernandez (2000) Human Capital Investment, Income Levels and Economic Grotwh in Latin American Countries. Departamento de Economics. Universidad Nacional Del Sur.

Lucas, R. E. (1988) On the Mechanics of Economic Development. Journal of Monetary Economics 22:1, 3-42.

Mankiw, N., D. Romer, and D. Weil (1992) A Contribution to the Empirics of Economic Growth. Quarterly Journal of Economics 107:2, 407-437.

Morck, R., D. Wolfenzon, and B. Yeung (2004) Corporate Governance, Economic Entrenchment and Growth (No. w10692). National Bureau of Economic Research.

OECD (1998) Human Capital Investment: An International Comparison. Technical Report, OECD, Paris.

Owen, A.L., J. Videras, and L. Davis (2009) Do all Countries Follow the Same Growth Process? Journal of Economic Growth 14:4, 265-286.

Sachs, J., J. W. McArthur, G. Schmidt-Traub, M. Kruk, C. Bahadur, M. Faye, and G. McCord (2004) Ending Africa Poverty Trap. Brookings Papers on Economic Activity $1,117-240$.

Schütt, F. (2003) The Importance of Human Capital for Economic Growth. Materialien des Wissenschaftsschwerpunktes Globalisierung der Weltwirtschaft 27, IWIM Institute for World Economics and International Management, University of Bremen.

Solow, R. M. (1956) A Contribution to the Theory of Economic Growth. The Quarterly Journal of Economics 70;1, 65-94.

Stark, O. and F. C. Simon (2007) The Brain Drain, Educated Unemployment, Human Capital Formation and Economic Betterment. Centre for Development Research, Bonn. (ZEF-Discussion Papers on Development Policy No. 114). 


\section{Comments}

Although the paper laid its foundation on well-established Benhabib and Spiegel, but how the reduced form equation 1 is derived from CobbDouglas is not properly mentioned in paper. Thus it is difficult to understand the channel between human capital and productivity through governance.

Beside other results paper also hint towards the threshold level of governance after which there might be diminishing return to scale. How this parabolic relationship is formed is not explained. Also, authors do not address the issue of non-linearity. Here I think more advanced methods like semi parametric techniques, which control the parameter heterogeneity problem can be considered.

Finally, to examine the effect of governance in growth regression why governance variable is not included in the regression itself? Why authors preferred to make sub samples?

National University of Science and Technology (NUST),

Asma Hyder

Islamabad. 